\title{
Gambaran Hasil Pemeriksaan Sitologi Cairan Asites di Instalasi Patologi Anatomi RSUD Arifin Achmad Provinsi Riau Periode Januari 2013 - Desember 2017
}

\author{
Ilhami Romus ${ }^{1 *}$, Ina Farida Rangkuti ${ }^{2}$, Vini Jum'atur Rahmah ${ }^{2}$
}

\begin{abstract}
Ascites is abnormal accumulation fluid in the peritoneal cavity. Many underlying disease can be responsible for causing ascites. Peritoneal fluid cytology remains the gold standard for detection of malignant cells in ascites which is useful in determining staging, treatment and prognosis. This aim of this study is to describe the characteristic of the result ascitic cytology examination at Anatomical Pathology Department of Arifin Achmad Hospital Period January 2013 - December 2018. This study reviewed the anatomy pathology data. A total of 171 cases consisted of $91.8 \%$ were females and males were $8.2 \%$. The highest number cases were in the age group of 41-50 years (26.9\%). Most ascitic fluid came from Department of Obstetric and Gynecology (81.9\%). The more frequent clinical diagnosis were ovarian carcinoma (19.3\%) and ovarian cyst (18.7\%). Most ascitic cytology examination results was positive cytology (64,9\%). Adenocarcinoma was commonest positive cytology $(46,2 \%)$.
\end{abstract}

Keywords : ascites, ascitic fluid, cytology examination, clinical diagnosis

Asites adalah akumulasi cairan abnormal di rongga peritoneum. ${ }^{1}$ Rongga peritoneum mengandung cairan serosa sebanyak $50-100 \mathrm{ml}^{2}{ }^{2}$ Peritoneum menyekresikan cairan serosa yang melumasi permukaan peritoneum dan memungkinkan pergerakan di antara kedua lapisan peritoneum. ${ }^{3}$ Menurut data dari American Association for the Study of Liver Desease (AASLD), sebagian besar penyebab asites di Amerika Serikat yaitu sirosis hati sebesar $85 \%$ sedangkan $15 \%$ disebabkan oleh penyakit non hepatik. ${ }^{4}$ Penyakit non hepatik yang dapat menyebabkan asites yaitu $10 \%$ disebabkan oleh keganasan atau asites maligna dan penyebab lainnya yaitu penyakit kardiogenik, nefrogenik, infeksi dan miscellaneous. ${ }^{5}$

Asites maligna didefinisikan sebagai suatu kondisi terdapat sel-sel ganas di dalam cairan asites. ${ }^{6}$

\footnotetext{
* Corresponding author : vini.jumatur.rahmah@gmail.com

1 Bagian Patologi Anatomi Fakultas Kedokteran Universitas Riau/KSM Patologi Anatomi RSUD Arifin Achmad Provinsi Riau. Pekanbaru

2 Fakultas Kedokteran Universitas Riau
}

Asites maligna lebih sering terjadi pada wanita yaitu sebesar $67 \%$ sedangkan $33 \%$ pada pria. Penyebab asites maligna yang paling sering yaitu $37 \%$ tumor ovarium, diikuti dengan $21 \%$ tumor pankreatobilier, $18 \%$ lambung, $4 \%$ esofagus, $4 \%$ kolorektal dan 3\% payudara. ${ }^{7}$ Mekanisme dasar terjadinya asites secara umum dapat diklasifikasikan menjadi dua yaitu transudasi dan eksudasi. ${ }^{8}$ Mekanisme transudasi terjadi akibat akumulasi filtrasi serum di dinding kapiler utuh secara fisik dengan aliran cairan melalui membran serosa melebihi proses reabsorpsi normal. Hal ini terjadi akibat peningkatan tekanan vena misalnya pada gagal jantung kongestif, sirosis hati, hipoproteinemia pada gagal ginjal. Mekanisme eksudasi terjadi akibat kerusakan pada percabangan dinding kapiler yang terdapat pada jaringan ikat serosa. Kerusakan ini menyebabkan keluarnya protein dan berbagai komponen sel darah masuk ke kavitas serosa sehingga dapat menimbulkan asites. ${ }^{9}$

Pemeriksaan sitologi cairan asites merupakan gold standar untuk mendeteksi adanya sel-sel ganas pada cairan asites. ${ }^{10}$ Hasil pemeriksaan ini 
berguna dalam penentuan tatalaksana, staging, dan prognosis penyakit. ${ }^{11}$ Penelitian yang dilakukan oleh Grandhi, dkk tahun 2014 mengenai gambaran mikroskopis yang ditemukan pada pemeriksaan sitologi cairan asites menunjukkan $82,14 \%$ proses radang, 9,52\% tumor ganas dan $8,34 \%$ curiga ganas. ${ }^{12}$ Tipe tumor ganas yang paling banyak ditemukan yaitu adenokarsinoma. ${ }^{13}$ Berdasarkan hal ini penulis tertarik mengetahui gambaran hasil pemeriksaan sitologi cairan asites di RSUD Arifin Achmad Provinsi Riau pada periode Januari 2013Desember 2017.

\section{METODE}

Jenis penelitian ini adalah penelitian deskriptif. Penelitian ini dilakukan dengan melihat data arsip patologi anatomi pasien yang dilakukan pemeriksaan sitologi cairan asites di RSUD Arifin Achmad Provinsi Riau periode Januari 2013 - Desember 2017. Penelitian ini dilaksanakan pada bulan MeiDesember 2018 dan dilakukan di Instalasi Patologi
Anatomi RSUD Arifin Achmad Provinsi Riau. Populasi dalam penelitian ini adalah seluruh data arsip patologi anatomi pasien yang dilakukan pemeriksaan sitologi cairan asites di Instalasi Patologi Anatomi RSUD Arifin Achmad Provinsi Riau periode Januari 2013 - Desember 2017. Pengambilan sampel pada penelitian ini adalah menggunakan metode total sampling. Variabel penelitian ini adalah karakteristik pasien meliputi jenis kelamin dan usia, KSM rumah sakit yang mengirim spesimen, diagnosis klinik dan gambaran sitologi cairan asites.

\section{HASIL}

Data penelitian ini diambil dari data pasien yang dilakukan pemeriksaan sitologi cairan asites bulan Januari 2013 sampai Desember 2017 yang terdapat di arsip Patologi Anatomi RSUD Arifin Achmad Provinsi Riau. Hasil yang diperoleh adalah terdapat 171 kasus pasien yang dilakukan pemeriksaan sitologi cairan asites. Berdasarkan sampel penelitian ini didapatkan karakteristik pasien yang dapat dilihat pada tabel 1 .

Tabel 1. Distribusi frekuensi karakteristik pasien yang dilakukan pemeriksaan sitologi cairan asites

\begin{tabular}{lll}
\hline Karakteristik Pasien & Frekuensi (n) & Persentase (\%) \\
\hline Jenis Kelamin & 14 & 8,2 \\
Laki-laki & 157 & 91,8 \\
Perempuan & 171 & 100 \\
\hline Total & & \\
Umur & 2 & 1,2 \\
$0-10$ tahun & 21 & 12,3 \\
$11-20$ tahun & 13 & 7,6 \\
$21-30$ tahun & 23 & 13,5 \\
$31-40$ tahun & 46 & 26,9 \\
$41-50$ tahun & 35 & 20,5 \\
$51-60$ tahun & 21 & 12,3 \\
$61-70$ tahun & 10 & 5,8 \\
$>70$ tahun & 171 & 100 \\
\hline Total & &
\end{tabular}

Berdasarkan tabel 1 didapatkan hasil bahwa pasien yang dilakukan pemeriksaan sitologi cairan asites paling banyak ditemukan berjenis kelamin perempuan yaitu sebanyak 157 orang $(91,8 \%)$. Berdasarkan karakteristik umur, didapatkan hasil bahwa kelompok umur terbanyak pada sampel penelitian ini adalah kelompok umur 41-50 tahun sebanyak 46 orang $(26,9 \%)$ dan yang paling sedikit ditemukan pada kelompok umur 0-10 tahun sebanyak 2 orang $(1,2 \%)$.

Distribusi frekuensi KSM rumah sakit pengirim spesimen cairan asites pada penelitian ini dapat dilihat pada tabel 2 . 
Tabel 2. Distribusi frekuensi KSM rumah sakit pengirim spesimen cairan asites

\begin{tabular}{lll}
\hline KSM Pengirim Spesimen & Frekuensi (n) & Persentase (\%) \\
\hline KSM Penyakit Dalam & 22 & 12,9 \\
KSM Bedah & 8 & 4,7 \\
KSM Obstetri dan Ginekologi & 140 & 81,9 \\
KSM Paru & 1 & 0,5 \\
\hline Total & 171 & 100 \\
\hline
\end{tabular}

Berdasarkan tabel 2 didapatkan hasil bahwa KSM rumah sakit yang paling banyak mengirimkan spesimen cairan asites adalah KSM Obstetri dan Ginekologi sebanyak 140 spesimen $(81,9 \%)$ dan yang paling sedikit berasal dari KSM Paru sebanyak 1 spesimen $(0,5 \%)$.

Distribusi diagnosis klinik pasien yang dilakukan pemeriksaan sitologi cairan asites pada penelitian ini dapat dilihat pada tabel 3.

Tabel 3. Distribusi diagnosis klinik pasien yang dilakukan pemeriksaan sitologi cairan asites

\begin{tabular}{|c|c|c|}
\hline Diagnosis klinik & Frekuensi (n) & Persentase (\%) \\
\hline Sirosis hati & 1 & 0,6 \\
\hline Aspergiloma paru & 1 & 0,6 \\
\hline Fibrocystic disease & 1 & 0,6 \\
\hline Germ cell tumor & 1 & 0,6 \\
\hline Granulosa cell tumor & 1 & 0,6 \\
\hline Hepatoma & 1 & 0,6 \\
\hline Karsinoma endometrium & 2 & 1,2 \\
\hline Karsinoma kolon & 1 & 0,6 \\
\hline Karsinoma mammae & 2 & 1,2 \\
\hline Karsinoma ovarium & 33 & 19,3 \\
\hline Karsinoma serviks & 2 & 1,2 \\
\hline Kista endometriosis & 2 & 1,2 \\
\hline Kista ovarium & 32 & 18,7 \\
\hline Kista uterus & 1 & 0,6 \\
\hline Leimiosarkoma & 1 & 0,6 \\
\hline Limfadenitis TB & 1 & 0,6 \\
\hline Limfoma & 1 & 0,6 \\
\hline Limfoma non Hodgkin & 1 & 0,6 \\
\hline Limfadenopati & 1 & 0,6 \\
\hline Mioma uteri & 1 & 0,6 \\
\hline Peritonitis kronik & 1 & 0,6 \\
\hline Sex cord-stromal & 1 & 0,6 \\
\hline Tumor adneksa & 3 & 1,8 \\
\hline Tumor ovarium & 12 & 7,0 \\
\hline $\mathrm{Tb}$ usus & 1 & 0,6 \\
\hline $\begin{array}{l}\text { Karsinoma ovarium,Karsinoma } \\
\text { endometrium }\end{array}$ & 1 & 0,6 \\
\hline Kista endometrium, mioma uteri & 1 & 0,6 \\
\hline $\begin{array}{l}\text { Karsinoma serviks, karsinoma } \\
\text { ovarium }\end{array}$ & 1 & 0,6 \\
\hline Kista ovarium, sirosis hati & 1 & 0,6 \\
\hline Kista ovarium, kista uterus & 1 & 0,6 \\
\hline Mioma uteri, karsinoma mammae & 1 & 0,6 \\
\hline Mioma uteri, kista ovarium & 1 & 0,6 \\
\hline Tidak ada data & 58 & 33,9 \\
\hline Total & 171 & 100 \\
\hline
\end{tabular}


Berdasarkan tabel 3 didapatkan hasil bahwa hasil diagnosis klinik yang paling banyak yaitu karsinoma ovarium sebanyak 33 kasus $(19,3 \%)$, kista ovarium sebanyak 32 kasus $(18,7 \%)$.
Distribusi gambaran sitologi cairan asites di RSUD Arifin Achmad Provinsi Riau tahun 2013 2017 dapat dilihat pada tabel 4 dibawah ini.

Tabel 4. Gambaran hasil pemeriksaan sitologi cairan asites di RSUD Arifin Achmad Provinsi Riau tahun $2013-2017$

\begin{tabular}{lll}
\hline Gambaran sitology & Frekuensi (N) & Persentase (\%) \\
\hline Negatif & 21 & 12,3 \\
- Radang non spesifik & 3 & 1,8 \\
- Radang spesifik TB & 1 & 0,6 \\
- Radang spesifik kandidiasis & 11 & 6,4 \\
- Tanpa kelainan bermakna & 19 & 11,1 \\
- Negative smear & 55 & 32,2 \\
Jumlah & 5 & 2,9 \\
Curiga ganas & & \\
Positif & 79 & 46,2 \\
- Adenokarsinoma & 1 & 0,6 \\
- Adenoskuamosa & 1 & 0,6 \\
- Limfoma non hodgkin & 20 & 11,7 \\
- Metastasis karsinoma & 10 & 5,8 \\
- Metastasis karsinoma dengan & & \\
inflammatory process & 111 & 64,9 \\
Jumlah & 171 & 100 \\
\hline Total & &
\end{tabular}

Berdasarkan tabel 4 didapatkan data bahwa gambaran hasil pemeriksaan sitologi cairan asites yang paling banyak adalah positif sebanyak 111 spesimen (64,9\%), diikuti dengan gambaran sitologi negatif sebanyak $55(32,2 \%)$ dan curiga ganas sebanyak $5(2,9 \%)$. Hasil penelitian ini juga menunjukkan bahwa dari seluruh hasil pemeriksaan cairan asites negatif yang paling banyak yaitu proses radang non spesifik sebanyak 21 spesimen (12,3\%) sedangkan dari seluruh hasil pemeriksaan sitologi cairan asites positif, adenokarsinoma merupakan gambaran sitologi terbanyak yang ditemukan yaitu sebanyak 79 spesimen $(46,2 \%)$.

\section{PEMBAHASAN}

Berdasarkan hasil penelitian didapatkan bahwa pasien yang dilakukan pemeriksaan sitologi cairan asites paling banyak berjenis kelamin perempuan yaitu sebanyak 157 orang $(91,8 \%)$. Hal ini sesuai dengan dengan penelitian Grandhi dkk di India yang menemukan proporsi pasien yang dilakukan pemeriksaan sitologi cairan asites berdasarkan jenis kelamin yang tertinggi adalah perempuan sebanyak $60,72 \% \cdot{ }^{14}$ Penelitian Hathila dkk di India tahun 2010 - 2012 juga menunjukkan rasio jumlah perempuan lebih besar dari laki-laki yaitu $3,4: 1 .{ }^{15}$ Penelitian ini berbeda dengan penelitian Shulbha V.S dan Dayananda B.S di India menunjukkan pemeriksaan sitologi cairan asites lebih sering pada pria sebanyak $59,8 \%$ dibanding wanita sebanyak $40,2 \% .{ }^{16} \mathrm{Hal}$ ini kemungkinan disebabkan karena pemeriksaan sitologi cairan asites dilakukan hanya ketika ada kecurigaan keganasan. ${ }^{17}$ Asites yang disebabkan keganasan lebih sering terjadi pada wanita yaitu sebesar $67 \%$ sedangkan 33\% pada pria. Penyebab asites maligna yang paling sering yaitu tumor ovarium. $^{7}$

Berdasarkan karakteristik umur, didapatkan hasil bahwa kelompok umur terbanyak pada sampel 
penelitian ini adalah kelompok umur 41-50 tahun sebanyak 46 orang $(26,9 \%)$ dan yang paling sedikit ditemukan pada kelompok umur 0-10 tahun sebanyak 2 orang $(1,2 \%)$. Hal ini sesuai dengan dengan penelitian Hathila dkk di India pada tahun 2010 2012 yaitu umur pasien yang dilakukan pemeriksaan sitologi cairan asites terbanyak usia 41-50 tahun yaitu sebanyak 46 orang $(28,05 \%)$ dan paling sedikit pada kelompok umur 0-10 tahun sebanyak 2 orang ( $1,22 \%$ ). Hal ini dikarenakan pada kelompok usia ini kejadian tumor ovarium meningkat.Tumor ganas ovarium meningkat dengan pesat sesudah usia 40 tahun, usia puncak adalah 50-60 tahun, secara bertahap akan turun setelah umur 70 tahun. Hal ini disebabkan karena ada beberapa faktor risiko yaitu subtipe histopatologi yang banyak pada tumor ganas ovarium, riwayat tumor ganas ovarium dalam keluarga, masa reproduksi yang panjang, kehamilan pertama setelah berusia lebih dari 30 tahun dan sebagainya sehingga terjadilah perbedaan umur yang didapat pada tumor ganas ovarium. ${ }^{18}$

Berdasarkan hasil penelitian didapatkan data bahwa KSM rumah sakit yang paling banyak mengirimkan spesimen cairan asites adalah KSM Obstetri dan Ginekologi sebanyak 140 spesimen $(81,9 \%)$ dan yang paling sedikit berasal dari KSM Paru sebanyak 1 spesimen (0,5\%). Hal ini sesuai dengan penelitian Karoo menunjukkan bahwa bagian rumah sakit yang meminta pemeriksaan sitologi cairan asites dari 276 spesimen yang dikirim berasal dari bagian Ginekologi sebanyak 114 spesimen, Penyakit Dalam sebanyak 77 spesimen, Bedah sebanyak 42 spesimen, Hematologi sebanyak 20 spesimen dan Onkologi sebanyak 23 spesimen. ${ }^{17}$ Asites maligna paling sering ditemukan pada neoplasma ginekologi terutama tumor ovarium. Pasien dengan tumor ovarium sebagian besar asimptomatik dan lebih dari $70 \%$ pasien didiagnosis pada stadium lanjut (stadium III / IV) dengan adanya metastasis di rongga peritoneum dan asites sehingga perlu upaya untuk deteksi dini tumor ovarium. ${ }^{11}$

Asites merupakan suatu manifestasi klinis yang dapat disebabkan oleh berbagai penyakit. Berdasarkan hasil penelitian menunjukkan diagnosis klinis yang paling banyak yaitu karsinoma ovarium sebanyak 33 kasus $(19,3 \%)$ dan kista ovarium sebanyak 32 kasus (18,7\%). Hasil penelitian ini berbeda dengan penelitian Kumar dkk, diagnosis klinis sitologi cairan asites yang paling banyak adalah sirosis hati sebanyak $42 \%$, tuberkulosis sebanyak $34,8 \%$, penyakit jantung dan ginjal sebanyak $8,4 \%$ dan neoplasma sebanyak $4,8 \%$ dan $10 \%$ tidak diketahui. Asites yang disebabkan neoplasma yang paling sering yaitu tumor ovarium dan saluran pencernaan. ${ }^{19}$ Hasil penelitian ini berbeda kemungkinan dikarenakan pemeriksaan sitologi cairan asites dilakukan jika terdapat curiga keganasan atau penyebab asites lainnya yang masih meragukan misalnya tidak terjadi penurunan PMN setelah 48 jam pengobatan antibiotik. ${ }^{7}$ Indikasi pemeriksaan sitologi cairan asites terdapat tiga krieria yaitu adanya riwayat kanker, tidak ada temuan fisik menunjukkan penyakit hepar dan jumlah spesimen asites awal dengan limfosit yang tinggi $\left(500 \mathrm{sel} / \mathrm{mm}^{3}\right)$ dan beberapa neutrofil. ${ }^{17}$

Pasien dengan sirosis hati yang menyebabkan asites tidak terkait dengan keganasan namun dokter melakukan paracentesis pada pasien ini seringkali mengirim cairan ke laboratorium sitologi atas adanya kecurigaan karsinoma hepatoseluler (HCC). Spesimen sitologi cairan asites pada pasien dengan sirosisbiasanya negatif. ${ }^{16}$ Patofisiologi utama asites maligna yaitu adanya peningkatan permeabilitas mikrovaskular dari pembuluh darah tumor. Penyebab lainnyayaitu adanya peningkatan neovaskularisasi peritoneum parietal, proses angiogenesis oleh faktor pertumbuhan endotel vaskular dan faktor permeabilitas vaskular, kerusakan dan remodeling matriks jaringan oleh matriks metalloproteinase dan adanya obstruksi limfatik. ${ }^{20}$

Sitologi merupakan ilmu yang mempelajari tentang morfologi sel-sel secara individual atau sel yang berasal dari fragmen jaringan yang diamati secara mikroskopis. Tujuan pemeriksaan sitologi adalah untuk menilai perubahan morfologi abnormal pada sel dari berbagai bagian tubuh manusia. ${ }^{21}$ Pemeriksaan ini penting untuk mendeteksi ada atau tidaknya sel kanker pada cairan tubuh. Selain itu juga dapat memberikan gambaran perubahan sel karena proses peradangan atau infeksi. ${ }^{14}$

Berdasarkan hasil penelitian yang didapatkan bahwa gambaran hasil pemeriksaan sitologi cairan asites yang paling banyak adalah positif sebanyak 111 spesimen $(64,9 \%)$. Hasil penelitian ini juga menunjukkan bahwa dari seluruh hasil pemeriksaan cairan asites negatif paling banyak yaitu proses 
radang non spesifik sebanyak 21 spesimen (12,3\%). Hal ini berbeda dengan penelitian yang dilakukan oleh Grandhi, dkk tahun 2014 mengenai gambaran mikroskopis yang ditemukan pada pemeriksaan sitologi cairan asites menunjukkan $82,14 \%$ proses radang $9,52 \%$ tumor ganas dan $8,34 \%$ curiga ganas. ${ }^{14} \mathrm{Hal}$ ini kemungkinan disebabkan karena pemeriksaan sitologi cairan asites dilakukan hanya ketika ada kecurigaan keganasan. ${ }^{12}$ Pemeriksaan sitologi cairan asites menunjukkan gambaran sitologi positifjika sel tumor berada pada lapisan peritoneum. Asites maligna adalah tanda karsinomatosis peritoneal dimana terdapat sel ganas di rongga peritoneum. Pasien dengan asites maligna memiliki tingkat kelangsungan hidup rata-rata 5,7 bulan setelah didiagnosis. Pada pasien karsinomatosis peritoneal memiliki sensitivitas hampir $97 \% .^{10}$

Penelitian Gupta dkk menunjukkan bahwa jenis tumor yang sering pada cairan asites yaitu jenis adenokarsinoma sebanyak $86,9 \%$ dan jenis tumor lainnya (limfoma, karsinoma sel skuamosa, mesothelioma dan lainnya) sebanyak $13,1 \% \cdot{ }^{13} \mathrm{Hal}$ ini tidak berbeda dengan hasil penelitian bahwa gambaran sitologi cairan asites positif berupa adenokarsinoma merupakan gambaran sitologi terbanyak yang ditemukan yaitu sebanyak 79 spesimen $(46,2 \%)$. Pemeriksaan sitologi sulit mendeteksi jenis tumor pada cairan asites. Kebanyakan spesimen dapat ditentukan jenis tumornya terutama metastasis dari jenis adenokarsinoma namun agak sulit menentukan jenis sel tumor lainnya pada beberapa spesimen. ${ }^{11}$

\section{SIMPULAN}

Pemeriksaan sitologi cairan asites paling banyak dilakukan pada perempuan daripada laki-laki dengan kelompok usia terbanyak 41-50 tahun. Spesimen cairan asites yang diterima di Instalasi Patologi Anatomi paling banyak berasal dari KSM Obstetri dan Ginekologi dengan diagnosis klinik karsinoma ovarium dan kista ovarium. Gambaran sitologi yang paling banyak yaitu positif sel tumor ganas dengan jenis adenokarsinoma.

\section{DAFTAR PUSTAKA}

1. Shikha NG. A cytological study of peritoneal fluids and its clinicobiochemical correlation . IOSR J Dent Med Sci. 2014;13(2):12-5

2. Tirkes T, Sandrasegaran S, Patel AA, Hollar MA, Tejada JG, Tan M, et al. Peritoneal and retro peritoneal anatomy and its relevance for crossimaging. radiographics. 2012;32:437-52.

3. Snelli RS. Anatomi klinis berdasarkan regio. 9th ed. Jakarta: EGC; 2013.

4. Runyon BA. Management of adult patients with ascites due to cirrhosis/ : Update 2012. Hepatology. 2012.

5. Huang L, Xia HH, Zhu S. Review article ascitic fluid analysis in the differential diagnosis of ascites/ : focus on cirrhotic ascites. J Clin Trans1 Hepatol. 2014;2:58-64.

6. Sangisetty SL, Miner TJ. Malignant ascites/: A review of prognostic factors, pathophysiology and therapeutic measures. World J Gastrointest Surg. 2012;4(4):87-95.

7. Barni S, Cabiddu M, Ghilardi M, Petrelli F. Anovel perspective for an orphan problem/: Old and new drugs for the medical management of malignant ascites. Elsevier. 2011;79:144-153.

8. Setiati S, Alwi I, Sudoyono AW, Simadibrata M, Setiyohadi B, Syam AF, editors. Buku ajar ilmu penyakit dalam. 4th ed. Jakarta: Interna Publishing; 2014.

9. Bibbo M, Wilbur DC. Comprehensive cytopathology. 3rd ed. Philadelphia: Saunders; 2008.

10.Jung M, Pützer S, Gevensleben H, Meller S, Kristiansen G, Dietrich D. Diagnostic and prognostic value of SHOX2 and SEPT9 DNA methylation and cytology in benign, paramalignant, and malignant ascites. Clin Epigenetics. 2016:1-13.

11. Zhang X, Chen L, Liu Y, Xu Y, Zhang X, Shi Y, et al. Improving the cytological diagnosis of highgrade serous carcinoma in ascites with a panel of complementary biomarkers in cell blocks. 2017:1-7. 
12. Oey RC, Buuren HR Van, Man RA De. The diagnostic work-up in patients with ascites/: current guidelines and future prospects. 2016;(8):330-5.

13. Gupta S, Sodhani P, Jain S. Cytomorphological profile of neoplastic effusions/: An audit of 10 years with emphasis on uncommonly encountered malignancies. J Cancer Res Ther. 2018;8(4):6029.

14.Grandhi B, Shanthi V, Rao NM, Reddy VC, Mohan KVM. The diagnostic utility of cell block as an adjunct to cytological smears. Int $\mathrm{J}$ Med Res Heal Sci. 2014;3(2):278-84

15. Hathila R, Dudhat R, Saini P, Italiya S, Kaptan K, Shah M. Diagnostic importance of serous fluid examination for detection of various pathological conditions - a study of 355 cases. 2013;2(4):9759.

16. Thrall MJ, Giampoli EJ. Routine review of ascites fluid from patients with cirrhosis or hepatocellular carcinoma is a low-yield procedure: An observational study.2009:6;1-6.
17. Karoo ROS, Llyod TDE, Garcea G, Redway HD, Robertson GSR. How valuable is ascitic cytology in the detection and management of malignancy/ ? 2003:79;292-4.

18. Rambe IR, Asri A, Adrial. Profil tumor ganas ovarium di Laboratorium Patologi Anatomi Fakultas Kedokteran Universitas Andalas Periode Januari 2011 sampai Desember 2012. 2014;3(1):54-7.

19. Bodal VK, Banasal P, Bal MS, Suri AK, Bhagat $\mathrm{R}$, Kaur $\mathrm{N}$ et al. Analysis of ascetic fluid for cytological and biochemical findings. 2013:2(4);98-104

20. Shulbha VS, Dayananda BS. Cytology of body fluids- an aid to primary diagnosis. Indian J Pathol Oncol. 2015;2(2):81-3.

21. Khristian E, Inderiati D. Sitohistoteknologi. 1st ed. Jakarta: Kementerian Kesehatan Republik Indonesia; 2017. 